\title{
Study on College English Teaching Strategy
}

\author{
Sixia Gao \\ Foreign Languages School, Qingdao University of Science and Technology, Qingdao 266061, China \\ E-mail:agnes0126@sina.com
}

This research is one part of a key human social science project named "Investigation on College English Teaching and Study on STSR English Teaching Strategy" in Qingdao University of Science and Technology in 2006.

\begin{abstract}
Using investigation and interview as the main research methods, the project team presents an experimental study on STSR (Note 1). In the investigation research, the project team chooses 66 college English teachers and nearly 600 non-English majors from Qingdao University of Science and Technology and makes an investigation of their teaching and learning processes respectively by attending lectures, issuing questionnaires, discussing and sample analyzing, etc. In the experimental study, the project team chooses 100 students as the one-year-STSR study sample and divides them into 2 groups (experimental group and control group) based on statistic principle. Data collected in the experiment and used in this paper are dealt with under the help of SPSS Software. The results show several problems in college English teaching in the university. In addition, influence of STSR on students' English learning is revealed. Several reformation suggestions and demonstration functions of STSR on college English teaching are thereby put forward.
\end{abstract}

Keywords: College English teaching, STSR teaching strategy, English teaching investigation, English learning investigation, Teaching reform

\section{Introduction}

Some problems were revealed in the results of an investigation (announced on April $2^{\text {nd }}$, 2004) on college English teaching and learning in 357 universities throughout China conducted by the Ministry of Education, which are as follows:

(1) Laggard teaching ideas, mainly reflected in the failure in coping with unity and diversity, insufficient stress on the comprehensive mastery of foreign languages but excessive emphasis on vocabulary teaching. (2) One-fold and out-of-date teaching patterns and methods. With most classes in large groups, a totally traditional one-way teaching is actually conducted in which teachers keep talking while students keep listening passively. According to investigations, only $37 \%$ of classes have less than 40 students and even 20 universities have over-80-student classes, which, of course, fails to encourage students' enthusiasm for English learning or to develop their comprehensive mastery of English. (3) Imperfect staff construction. Firstly, with their heavy loads of work, most teachers have no time or energy for teaching research or training; secondly, seen from the aspect of titles (only $27.1 \%$ of them with senior titles and as many as $33.1 \%$ are assistants, $72 \%$ with bachelor's degree and only $22 \%$ with master's degree or the above), the whole staff need improving; thirdly, due to some reasons in treatment and title assessment, some teachers are less responsible for their teaching, influencing college English teaching to some extent. (4) Exam-oriented teaching pattern is still in existence. Due to some teachers' poor knowledge of Band 4 and Band 6 examinations, excessive emphasis has been put on passing exams. Such an exam-oriented teaching will, of course, fail to improve students' practical abilities in English or to help students to enjoy the great interest in English learning.

It is shown in the above investigations that some factors have influenced China's college English teaching, especially caused students' poor English capacities. It should be realized that college English, above all, is an organic part of higher education. Education, just as its name suggests, involves "to develop" as well as "to teach". Just as Professor Lu Gusun once said, plentiful exercises tactics and skill training which are over mechanical and only take the specific requirements relevant to future vacation instead of all-round development as the ultimate goal have narrowed some students' thoughts and neglected their cultivation. In addition, according to Einstein, professional knowledge input tends to turn students into useful machines, not persons able to develop harmoniously (Zhang, 1999, p 119). A college English learner is expected to learn how to learn English independently, to have high comprehensive cultural quality as well as a proficient command of English. As far as EFL learners are concerned, an effective learning method suitable for themselves is particularly important (Wu, 2005). According to widely accepted Sapir-Whorf Hypothesis, the structure of the language people habitually use influence the ways they think and behave (Dai \& He, 2002, p.130). Consequently, English teaching involves not only language itself, but the culture in which it originates, even the thoughts and behaviors embodied in the culture. In addition, with no stereotyped method for English teaching, specific methods should be explored for different students. 
In Qingdao University of Science and Technology in which the project team is located, all classes have over 50 students. In the aspect of staff, in spite of the fact that nearly $65 \%$ of teachers have master's degree, only $52.7 \%$ teachers have taught over 6 years in universities, only $18.5 \%$ have taught over 10 years, only $14.5 \%$ of them are associate professors or above and only 1 teacher is a professor. As is shown in the above statistics, the structure of college English teachers in this university is not so reasonable. In China's new reform of college English, teachers' teaching methods and their practical utility of these methods are particularly critical. Therefore, although our university is not among the 180 demonstration universities listed by the Education Ministry in 2004, the project team has conducted research on the college English teaching strategies in our university in order to improve our college English teaching, convert teachers' ideas and to optimize class teaching, in which we have been devoted to investigating college English teachers' teaching methods and means, exploring methods suitable for our practical situation, providing empirical support for the theoretical research on our college English teaching strategy, analyzing STSR (Special Teaching Strategy and Research) and putting it into teaching practice.

\section{Research Method and Sample Selection}

\subsection{Preparatory Research Result}

It is shown in the preparatory investigation that a universal teaching method is used for students majoring in arts, science as well as engineering, hence lacking in practicability and individuality. Actually, teaching strategy is more or less related to the operation of teaching institutions, social and cultural background, teachers' teaching ideas and their personality, teachers' learning as well as teaching experience. In addition, not only the form of Band 4 and Band 6 Test but some factors related to learners (size of class, cognitive style, motivation, emotion, current language ability, leaning ideas, etc.) play an important role in teaching methods and teachers' roles. In a word, a variety of teaching factors interact with each other, influencing teaching strategy directly or indirectly. In our opinion, an effective teaching method should be based on different characteristics of different majors and the diversity of learners at different levels.

\subsection{Methods and Sample Selection of STSR Teaching Strategy Research}

\subsubsection{Questionnaire Investigation, Interview and Sample Selection}

From March 2006 to March 2008, the project team conducted an investigation on 66 college English teachers and 600 learners selected randomly from Grade 2005 and Grade 2006 (Note 2) by attending lectures, holding discussion sessions, issuing questionnaires and analyzing samples. In order to ensure the validity of the investigation, we have selected male and female learners in nearly the same proportion as that between male and female students in the whole university and nearly the same number of students from Grade 2005 and 2006 respectively. Altogether 66 questionnaires were delivered to teachers, 55 of which were valid (validity rate: $90 \%$ ) and 600 questionnaires were given to students, 593 of which were valid (validity rate: $98.8 \%$ ). When designing our questionnaires, we referred to the questionnaire pattern in A Research on English Talent Cultivation Pattern Featuring the Coordination from Primary School to University (Mei, 2004, Appendix) and a thesis collection named The Key to English Learning (Wen, 2003, Appendix) and adopted "7-Grade Difference" as the core of question design. Besides, SPSS software was used to process relevant data.

\subsubsection{Comparative Method and Sample Selection}

Table 1. The difference in English capacity between experimental class and control class $(\mathrm{X} \pm \mathrm{S})$

\begin{tabular}{ccccccc}
\hline Class & $\mathrm{N}$ & Listening & Speaking & Reading & Writing & Comprehensive \\
\hline $\begin{array}{c}\text { Experimental } \\
\text { class }\end{array}$ & 50 & $11.20 \pm 4.37$ & $13.76 \pm 5.67$ & $17.16 \pm 5.97$ & $14.22 \pm 6.53$ & $56.29 \pm 21.98$ \\
\hline Control class & 50 & $11.79 \pm 4.71$ & $14.74 \pm 5.54$ & $16.52 \pm 6.26$ & $13.66 \pm 6.25$ & $56.57 \pm 22.09$ \\
\hline $\mathrm{T}$ & -0.55 & -0.74 & 0.47 & 0.38 & -0.07 \\
\hline $\mathrm{p}$ & $>0.05$ & $>0.05$ & $>0.05$ & $>0.05$ & $>0.05$ \\
\hline
\end{tabular}

In our questionnaire investigation, 100 students from Grade 2005 were selected randomly as comparative research samples. They were divided into two classes according to their pre-experiment English level and the proportion between male and female students, one of which was trained in English with STSR teaching strategy (experimental class) while the other was taught with the universal teaching method (control class) for an academic year. In order to prove whether there is obvious difference in English capacity between the two classes, the project team conducted pre-experiment tests in listening, speaking, reading, writing and comprehensive abilities, the result of which is shown in Table 1. According to this table, there is no obvious difference between the two groups before our experiment.

The parallel method was adopted in the whole comparative research, as is shown in Table 2. Then T test was conducted to analyze the result of our experiment. 
Table 2. The pattern of parallel experimental design

\begin{tabular}{c|c|c|c}
\hline Group & \multicolumn{3}{|c}{ Experimental process } \\
\hline Experimental group & $\begin{array}{c}\text { Pre-experiment } \\
\text { assessment }\end{array}$ & STSR teaching & $\begin{array}{c}\text { After-experiment } \\
\text { assessment }\end{array}$ \\
\hline Control group & $\begin{array}{c}\text { Pre-experiment } \\
\text { assessment }\end{array}$ & $\begin{array}{c}\text { Common college } \\
\text { English teaching }\end{array}$ & $\begin{array}{c}\text { After-experiment } \\
\text { assessment }\end{array}$ \\
\hline
\end{tabular}

After the experiment, the two classes were tested at the same difficulty level and the students from the experimental class were surveyed about their psychological reactions to STSR teaching method in the form of questionnaires, hence drawing the conclusion about the influence STSR teaching method has on college English teaching.

\section{Result and Analysis}

\subsection{Investigation Statistics and Analysis}

It is shown in our investigation that an insufficient number of teachers are burdened with excessive workload, there is a severely unreasonable staff structure in terms of age, gender, title and knowledge and too little time has been spent on research.

\subsubsection{Insufficient Teachers and Heavy Workload}

In spite of the great efforts in introducing excellent teachers in Qingdao University of Science and Technology, there is still a severe shortage in college English teachers. 66 teachers have to take up English classes for 9000 undergraduates and over 1000 postgraduates. Accordingly, they have over 10 periods every week on average and nearly $60 \%$ of them have over 12 periods. All classes have a large size, over 50 students.

3.1.2 Unreasonable Staff Structure in Age, Gender, Title and Knowledge (shown in Table 3)

Table 3. The Survey of college English teachers' background in Qingdao University of Science and Technology

\begin{tabular}{|c|c|c|c|c|c|}
\hline Items & \multicolumn{5}{|c|}{ Statistical results } \\
\hline \multirow{2}{*}{ Gender } & \multicolumn{3}{|c|}{ Male } & \multicolumn{2}{|c|}{ Female } \\
\hline & \multicolumn{3}{|c|}{$10,18.2 \%$} & \multicolumn{2}{|c|}{$45,81.8 \%$} \\
\hline \multirow[t]{2}{*}{ Major } & $\begin{array}{l}\text { English } \\
\text { teaching }\end{array}$ & Linguistics & Literature & Translation & Others \\
\hline & 10 & 13 & 16 & 8 & 8 \\
\hline \multirow{2}{*}{ Age } & \multicolumn{2}{|l|}{$\leq 25$} & $25-35$ & $5-45$ & $\geq 45$ \\
\hline & $2,3.6 \%$ & \multicolumn{2}{|c|}{$42,76.4 \%$} & $16.4 \%$ & $2,3.6 \%$ \\
\hline \multirow{2}{*}{$\begin{array}{l}\text { Where to } \\
\text { come from }\end{array}$} & \multicolumn{2}{|c|}{ Urban area } & Town & \multicolumn{2}{|c|}{ Countryside } \\
\hline & \multicolumn{2}{|c|}{$31,56.4 \%$} & $14,25.4 \%$ & \multicolumn{2}{|c|}{$10,18.2 \%$} \\
\hline \multirow[t]{2}{*}{$\begin{array}{c}\text { Education } \\
\text { background }\end{array}$} & Bachelor & $\begin{array}{l}\text { Master's } \\
\text { degree } \\
\text { candidate }\end{array}$ & Master & $\begin{array}{l}\text { Doctor's } \\
\text { degree } \\
\text { candidate }\end{array}$ & Doctor \\
\hline & $11,20.0 \%$ & $9,16.4 \%$ & $34,61.8 \%$ & $1,1.8 \%$ & $0,0.0 \%$ \\
\hline \multirow{2}{*}{$\begin{array}{l}\text { Length of } \\
\text { teaching }\end{array}$} & $\leq 2$ & $2-5$ & $6-10$ & $11-20$ & $\geq 20$ \\
\hline & $10,18.2 \%$ & $14,25.4 \%$ & $21,38.2 \%$ & $5,9.1 \%$ & $5,9.1 \%$ \\
\hline Title & Assistant & Lec & & $\begin{array}{l}\text { ciate } \\
\text { essor }\end{array}$ & Professor \\
\hline & $20,36.4 \%$ & 27,4 & & $.7 \%$ & $1,1.8 \%$ \\
\hline
\end{tabular}

According to an investigation conducted by Xia Jimei in 2000 and 2001, English teachers with master's degree only accounted for $22.9 \%$ of the total (Xia, 2002, p.35). As is shown in Mei Deming's questionnaire survey based on 44 universities and 447 valid questionnaires in 2004, 62.25\% of the examinees had taught less than 5 years, $60.88 \%$ of them were assistants and $65 \%$ of them were graduates (Mei, 2004, p.72). As is revealed in Table 3, among all the college English teachers in Qingdao Universities of Science and Technology, 63.6\% of them have master's degree; the ratio between male and female teachers is 1:4.5; about $80 \%$ of them are below 35 years old; $43.6 \%$ of them have taught less than 5 years and $81.8 \%$ less than 10 years; $36.4 \%$ are assistants, $49.1 \%$ are lecturers, only $14.5 \%$ are associate 
professors and only 1 is a professor. Obviously, due to a great number of teachers introduced in the recent years, the education background of the college English teachers in our university is far better than the average national level several years ago. However, some problems are still hindering the sound development of our college English teaching, such as an excessively large proportion of young teachers, especially young women teachers as well as assistants, insufficient education background compared with the teachers in other majors (none with doctor's degree) and the severely imbalanced gender ratio. Besides, in the aspect of theory, only a few teachers have learned theories on language teaching and less than $40 \%$ of them are equipped with theories on second language acquisition and English teaching.

\subsubsection{Little Time on Research and Research Activities with Mere Formality}

Due to their heavy workload, most teachers have no enough energy for both teaching and research. In this case, even those young teachers specialized in English teaching will not be devoted to the research on course books and teaching methods and still turn to the traditional methods to teach, even only following the fixed rules. Just as is shown in the questionnaires, this method has hardly achieved favorable effects.

Table 4. Students' evaluation on their college English teachers

\begin{tabular}{|c|c|c|c|c|c|c|c|}
\hline Items & $\begin{array}{c}\text { 1.Totall } \\
\mathrm{y} \\
\text { satisfied }\end{array}$ & $\begin{array}{c}\text { 2.Satisfie } \\
\mathrm{d}\end{array}$ & $\begin{array}{c}\text { 3.Basicall } \\
\text { y satisfied }\end{array}$ & $\begin{array}{c}4 . \text { Mild } \\
\text { satisfied }\end{array}$ & $\begin{array}{c}5 . \\
\text { Basically } \\
\text { dissatisfi } \\
\text { ed }\end{array}$ & $\begin{array}{c}6 . \text { Dissatisfie } \\
\mathrm{d}\end{array}$ & $\begin{array}{c}\text { 7.Totally } \\
\text { dissatisfie } \\
\mathrm{d}\end{array}$ \\
\hline $\begin{array}{l}\text { Number of } \\
\text { students }\end{array}$ & 9 & 17 & 86 & 180 & 209 & 56 & 36 \\
\hline Percentage & $1.53 \%$ & $2.87 \%$ & $14.50 \%$ & $30.35 \%$ & $35.24 \%$ & $9.44 \%$ & $6.07 \%$ \\
\hline
\end{tabular}

Furthermore, we have found in our investigation that the current situation of college English teachers' research achievements gives some cause for anxiety. 58.18\% teachers have no experience in compiling course books or have no idea about that; over $54.55 \%$ of them haven't participated in any teaching research projects, not to mention hosting any, or have no idea about how to apply for it and how to write a project argument; $41.82 \%$ of them haven't done any mathematical statistics or don't know how to do that; and only $16.36 \%$ of them have experience in quantitative and qualitative research methods.

Among all the theses published by the teachers, only $27.27 \%$ of them have some original ideas or are based on careful study and only a few have been published on widely acknowledged core journals. Besides, as many as $87.27 \%$ of the teachers haven't been abroad for advanced course; $90.91 \%$ of them haven't attended any foreign language teaching seminars held abroad, which is much higher than the statistics of $84 \%$ and $84 \%$ respectively given by Xia Jimei in her investigation. With college teachers' important role in not only cultivating high-quality talents but also promoting scientific research, this current situation really calls for our attention. In order to improve students' English level, college English teachers' quality should be improved first.

\subsection{The Result of Comparative Experiment and Analysis}

\subsubsection{The Influence of STSR on Students' Overall English Capacities}

Table 5. The comparison between the two classes' English capacities $(\mathrm{X} \pm \mathrm{S})$

\begin{tabular}{c|ccccccc}
\hline English capacity & Class & $\mathrm{N}$ & $\begin{array}{c}\text { Pre-experiment } \\
\text { assessment }\end{array}$ & $\begin{array}{c}\text { After-experiment } \\
\text { assessment }\end{array}$ & $\mathrm{r}$ & $\mathrm{t}$ & $\mathrm{p}$ \\
\hline \multirow{5}{*}{ Listening } & Experimental & 50 & $11.20 \pm 4.37$ & $12.96 \pm 3.28$ & 0.93 & $5.02^{* *}$ & $<0.01$ \\
& class & & & & & \\
& Control class & 50 & $11.78 \pm 4.71$ & $12.29 \pm 5.22$ & 0.91 & 1.08 & $>0.05$ \\
& $\mathrm{~T}$ & & -0.54 & 1.37 & & & \\
& $\mathrm{P}$ & & $>0.05$ & $>0.05$ & & & \\
\hline \multirow{5}{*}{ Speaking } & Experimental & 50 & $13.76 \pm 5.67$ & $15.65 \pm 4.65$ & 0.94 & 4.08 & $<0.05$ \\
& class & & & & & \\
& Control class & 50 & $14.74 \pm 5.54$ & $15.01 \pm 5.49$ & 0.91 & 0.56 & $>0.05$ \\
& $\mathrm{~T}$ & & -0.74 & 1.28 & & & \\
\hline
\end{tabular}




\begin{tabular}{|c|c|c|c|c|c|c|c|}
\hline \multirow{4}{*}{ Reading } & $\begin{array}{l}\text { Experimental } \\
\text { class }\end{array}$ & 50 & $17.16 \pm 5.97$ & $20.59 \pm 4.76$ & 0.93 & $11.19^{* *}$ & $<0.01$ \\
\hline & Control class & 50 & $16.53 \pm 6.26$ & $16.54 \pm 6.56$ & 0.85 & 0.04 & $>0.05$ \\
\hline & $\mathrm{T}$ & & 0.46 & $2.81^{* *}$ & & & \\
\hline & $\mathrm{P}$ & & $>0.05$ & $<0.01$ & & & \\
\hline \multirow{4}{*}{ Writing } & $\begin{array}{c}\text { Experimental } \\
\text { class }\end{array}$ & 50 & $14.22 \pm 6.53$ & $19.32 \pm 5.54$ & 0.97 & $16.43^{* *}$ & $<0.01$ \\
\hline & Control class & 50 & $13.67 \pm 6.25$ & $13.71 \pm 7.22$ & 0.95 & 0.32 & $>0.05$ \\
\hline & $\mathrm{T}$ & & 0.39 & $2.97^{* *}$ & & & \\
\hline & $\mathrm{P}$ & & $>0.05$ & $<0.01$ & & & \\
\hline \multirow{4}{*}{ Comprehensive } & $\begin{array}{c}\text { Experimental } \\
\text { class }\end{array}$ & 50 & $56.29 \pm 21.98$ & $68.61 \pm 17.29$ & 0.97 & $11.82^{* *}$ & $<0.01$ \\
\hline & Control class & 50 & $56.58 \pm 22.09$ & $57.39 \pm 22.80$ & 0.95 & 0.78 & $>0.05$ \\
\hline & $\mathrm{T}$ & & -0.08 & $2.26^{*}$ & & & \\
\hline & $\mathrm{P}$ & & $>0.05$ & $<0.05$ & & & \\
\hline
\end{tabular}

The comparative result between the experimental and control class throughout the whole experiment is shown in Table 5, in which the vertical columns display the comparison between the two classes' English capacities while the horizontal ones display the comparison between their pre-experimental English capacities and after-experimental ones.

According to Table 5, students in the experimental class have made rapid progress in their English capacities after one-year STSR training $(\mathrm{P}<0.01$ except for speaking in which $\mathrm{P}<0.05)$, while those in the control class haven't improved their English greatly $(\mathrm{P}>0.05)$. In addition, there is obvious difference between the two classes' comprehensive English capacities $\left(\mathrm{t}=2.26^{*}, \mathrm{P}<0.05\right)$ especially in reading and writing $\left(\mathrm{t}=2.81^{*}, 2.97^{*}, \mathrm{p}<0.01\right)$. However, there is no obvious difference in their listening and speaking capacities. That is to say, in spite of STSR's function in improving students' English reading, writing and comprehensive English capacities, it is not so effective in speaking and listening.

\subsubsection{The Influence of STSR on Different Students' English Capacities}

In order to further study STSR's influence on students' English capacities, the project team also made a comparative research on students at different levels (three levels including excellent, intermediate and poor students). The result is displayed in Table 6.

Table 6. The comparison among different students' English capacities

\begin{tabular}{|c|c|c|c|c|c|c|}
\hline \multirow{2}{*}{ Group } & \multicolumn{2}{|c|}{ Excellent students } & \multicolumn{2}{|c|}{ Intermediate students } & \multicolumn{2}{|c|}{ Poor students } \\
\hline & $\begin{array}{c}\text { Pre- } \\
\text { experiment } \\
\text { assessment }\end{array}$ & $\begin{array}{c}\text { After- } \\
\text { experiment } \\
\text { assessment }\end{array}$ & $\begin{array}{c}\text { Pre- } \\
\text { experiment } \\
\text { assessment }\end{array}$ & $\begin{array}{c}\text { After- } \\
\text { experiment } \\
\text { assessment }\end{array}$ & $\begin{array}{l}\text { Pre-experiment } \\
\text { assessment }\end{array}$ & $\begin{array}{l}\text { After-experiment } \\
\text { assessment }\end{array}$ \\
\hline \multirow{2}{*}{ Listening } & $16.17 \pm 1.52$ & $16.55 \pm 2.14$ & $11.54 \pm 2.31$ & $12.02 \pm 1.84$ & $6.25 \pm 2.47$ & $10.21 \pm 2.90$ \\
\hline & $\mathrm{t}=0.75$ & $p>0.05$ & $\mathrm{t}=0.81$ & $p>0.05$ & $\mathrm{t}=5.96^{* *}$ & $\mathrm{p}<0.01$ \\
\hline \multirow{2}{*}{ Speaking } & $20.21 \pm 1.61$ & $20.41 \pm 1.80$ & $14.25 \pm 2.91$ & $16.76 \pm 3.60$ & $6.98 \pm 1.89$ & $11.24 \pm 2.52$ \\
\hline & $\mathrm{t}=0.44$ & $p>0.05$ & $\mathrm{t}=2.86^{* *}$ & $\mathrm{p}<0.01$ & $\mathrm{t}=6.01^{* *}$ & $\mathrm{p}<0.01$ \\
\hline \multirow{2}{*}{ Reading } & $25.12 \pm 1.44$ & $26.50 \pm 1.92$ & $17.02 \pm 2.34$ & $20.01 \pm 2.02$ & $10.94 \pm 1.87$ & $15.95 \pm 1.57$ \\
\hline & $\mathrm{t}=6.12^{* *}$ & $\mathrm{p}<0.01$ & $\mathrm{t}=8.26^{* *}$ & $\mathrm{p}<0.01$ & $\mathrm{t}=15.22^{* *}$ & $\mathrm{p}<0.01$ \\
\hline \multirow{2}{*}{ Writing } & $21.94 \pm 2.31$ & $23.15 \pm 0.95$ & $14.25 \pm 2.78$ & $19.27 \pm 2.24$ & $6.05 \pm 2.84$ & $12.14 \pm 2.34$ \\
\hline & $\mathrm{t}=5.62^{* *}$ & $\mathrm{p}<0.01$ & $\mathrm{t}=11.12^{* *}$ & $\mathrm{p}<0.01$ & $\mathrm{t}=22.13^{* *}$ & $\mathrm{p}<0.01$ \\
\hline \multirow{2}{*}{ Comprehensive } & $84.05 \pm 5.34$ & $89.92 \pm 5.27$ & $57.12 \pm 9.78$ & $71.45 \pm 8.23$ & $31.05 \pm 7.31$ & $47.97 \pm 6.34$ \\
\hline & $\mathrm{t}=8.95^{* *}$ & $\mathrm{p}<0.01$ & $\mathrm{t}=11.03^{* *}$ & $\mathrm{p}<0.01$ & $\mathrm{t}=18.57^{* *}$ & $\mathrm{p}<0.01$ \\
\hline
\end{tabular}

According to Table 6, intermediate, poor as well as excellent students have achieved great progress during the experiment (excellent: $\mathrm{t}=8.95^{* *}, \mathrm{P}<0.01$; intermediate: $\mathrm{t}=11.03^{* *}, \mathrm{p}<0.01$; poor: $\mathrm{t}=18.57^{* *}, \mathrm{p}<0.01$ ), which proves STSR's great influence on students at different levels, especially excellent and intermediate students due to their greater 
concern about teachers' teaching styles, some information related to their majors and their prospect. In reading and writing, STSR takes great effects $(\mathrm{P}<0.01)$, especially for intermediate and poor students; as for listening and speaking, STSR has different influences on different students (no obvious influence on excellent students' listening as well as speaking: P $>0.05$; no obvious influence on intermediate students' listening while important for their speaking; important for poor students' listening and speaking: $\mathrm{P}<0.05$ ). The above result shows its great importance in intermediate and poor students' listening and speaking.

\subsubsection{Summary of Comparative Experiment}

The following findings have been made in our comparative experiment: 1) if used reasonably, STSR can help students to develop their English potentials and therefore to develop their English capacities in examinations and communication. Besides, comparatively, STSR has greater influence on excellent and intermediate students than on poor ones due to their less attention to teachers' summary than the basic knowledge in their course books caused by their low English level. 2) when students at different levels are compared, STSR mainly takes effects in their reading and writing abilities instead of speaking and listening ones. After all, students' interest in English will influence their enthusiasm for English learning, hence causing different effort they make when learning a language. As for STSR, it mainly focuses on students' written capacities instead of oral ones (quite similar to the traditional teaching method in this aspect). 3) due to great importance on knowledge extension in STSR, intermediate and poor students will be helped a lot in their reading capacities.

\section{Conclusion}

According to the above investigation, statistics and comparative experiment, the following points should be attached importance to in order to improve teachers' English teaching as well as students' English learning.

\subsection{Lessening College English Teachers' Workload}

Only with less workload will college English teachers have time and energy to study students and teaching methods carefully, hence constantly updating their own knowledge structure, providing students with what they really need to improve their English capacities.

\subsection{Taking Measures to Give Teachers Opportunity in Advanced Studies}

Teachers' teaching process is accompanied by learning activities. Both new and old teachers are expected to update their knowledge structure from time to time. During this course, experienced teachers should give guidance on new teachers' teaching ideas, teaching methods, teaching theories and research methods. Meanwhile, new teachers should attach importance to psychology, philosophy, morality and other courses related to their professional quality. Besides, more opportunity should be created for teachers to go abroad for further study, during which they will have access to foreign culture, hence more capable of cultivating high-quality students.

\subsection{Carrying out Teaching Research Activities}

Only in teaching research activities, teachers have chance to discuss with each other to overcome their shortcomings by learning from others' strengths, to equip themselves with perfect teaching methods and means and to teach students in a scientific and effective way.

\subsection{STSR's Demonstrative Effect on College English Teaching}

The three aspects including language skills, knowledge and quality should be emphasized in college English teaching. No matter in class-based reading and writing courses or computer/network-based audiovisual courses, both students' basic knowledge and their practical abilities especially those in listening, speaking and writing should be focused on. Meanwhile, they should be taught about the art of public speaking, argumentation, communication as well as their expressive abilities and wide knowledge. In short, emphasis should be shifted from imitation to independent thinking and profound cognition, in which students begin with collecting useful information, then proceed to acquire knowledge they need, summarize their experience and finally embody it into their intelligence

Certainly, STSR teaching strategy is only a microcosm of all, hence not able to replace others. However, it is found that this strategy really has done a lot in improving students' English capacities. During their teaching course, teachers are expected to expand their mind, improve their teaching standard, explore more scientific and effective methods in order to stimulate students' enthusiasm and passion for English learning and improve their English capacities consequently. We hope that our investigation will be followed by greater achievements in this field.

\section{References}

Dai, Weidong \& He, Zhaoxiong. (2002). New Brief Course of English Linguistics. Shanghai: Shanghai Foreign Language Education Press. pp. 130-131.

Lu, Gusun. (1999). Three Reflections on English Teaching. A Collection of English Education Scholars' Opinions. Beijing: Foreign Language Teaching and Research Press. pp.119-123. 
Mei, Deming. (2004). An Investigation of English Teaching in Universities, Middle and Primary Schools. Shanghai: Shanghai Foreign Language Education Press. p. 72.

Mei, Deming. (2004). A Research on English Talent Cultivation Pattern Featuring the Coordination from Primary School to University. Shanghai: Shanghai Foreign Language Education Press. Appendix.

Wen, Qiufang. (2003). The Key to English Learning. Shanghai: Shanghai Foreign Language Education Press. Appendix. Wu, Hongzhi. (2005). MRLS in English Study. Chengdu: University of Electronic Science and Technology of China.

Wu, Qidi. (2004). A Talk on the Reform in Band 4 and Band 6 Test by Vice Minster of Education: A Talk at the Video Conference on College English Teaching Reform Trials (extract). Beijing: The Ministry of Education of China. April $2^{\text {nd. }}$.

Xia, Jimei. (2002). An Investigation on College English Teachers' Education Ideas, Knowledge, Ability, Research and Training. Foreign Language World. 5: pp, 35-41.

\section{Notes}

Note 1. STSR is the abbreviation for Special Teaching Strategy and Research, which means different strategies should be used for different majors.

Note 2. The project team conducted investigations on college English teachers and non-English students respectively. The former covers teachers' teaching background, teaching interest, emotion and ideas, their preference for different teaching methods or means while the latter mainly includes students' learning background, size of class, current language level, motivation, learning ideas, emotional factors, evaluation of teachers' teaching methods, learning habits and styles and so on. All the data in this article come from our investigation. 